\title{
Presepsi Mahasiswa : Pemotivasian Belajar Melalui Repositori Dengan Hasil Belajar Pada Masa Pandemi COVID-19
}

\author{
Andar Gunawan Pasaribu ${ }^{1}$ \\ ${ }^{1}$ Prodi Pendidikan Agama Kristen, Institut Agama Kristen Negeri Tarutung
}

\begin{abstract}
Abstrak
Penelitian ini bertujuan untuk mengembangkan strategi pembelajaran motivasi dari gudang untuk hasil belajar siswa. Penelitian ini dilakukan pada siswa IAKN Tarutung dengan menggunakan metode penelitian pengembangan. Pengembangan dilakukan melalui tahapan yaitu symbol, development tools, kemudahan mengakses repositori. kelengkapan bahan perkuliahan, dan tempat penyimpanan efektif. Hasil pengujian penggunaan application repository dengan nilai rata-rata $88 \%$.
\end{abstract}

KataKunci: Repository, motivasi, hasil belajar

\begin{abstract}
This study aims to develop strategies learning motivational from the repository for student learning outcomes. . This research was conducted on IAKN Tarutung students by using the development research method. Development is carried out through stages, namely symbol, development tools, ease of accessing the repository. completeness of lecture materials, and the Effective repository. The results of testing the use of applications repository with an average value of $88 \%$.
\end{abstract}

Keywords: Repository, motivation, learning outcomes

\section{PENDAHULUAN}

Perkembangan teknologi informasi membawa transformasi dan perkembangan pendidikan (Perttersson, 2016). Castells juga mengomentari masalah "Teknologi tidak mendefinisikan masyarakat, teknologi adalah masyarakat" (di dalam Netwerkgtoe, M. Castells, 1996. 158-163,). Laju perubahan yang cepat mungkin menjadi alasan bahwa banyak orang melihat teknologi sebagai sesuatu yang "diberikan" kepada orang-orang sementara pengertian tentang keberadaan teknologi atau perasaan yang mereka gunakan dalam proses belajar mengajar tidak sepenuhnya jelas. Namun seperti yang dinyatakan oleh Levy (P. Lévy, 1998 hal. 76,). Lebih lanjut Lev Manovich (2001) membahas tentang lima prinsip yang muncul dari sifat digitalnya, yaitu representasi numerik, modularitas, otomasi, variabilitas dan transcoding (L. Manovich, hlm. 3642).

Mahasiswa dapat belajar kapan saja, di mana saja, sesuai dengan gaya belajar mereka yang paling efektif, dengan kecepatan yang dapat dimodifikasi untuk kebutuhan individu. Pembelajaran digital

78 | Korespondensi mengenai artikel dapat dilakukan kepada: Andar Gunawan Pasaribu, Institut Agama Kristen Negeri Tarutung, Jl. Raya Tarutung-Siborong KM 11, Silangkitang, Sipoholon, Tapanuli Utara (22452), Indonesia e-mail Corresponding: pdt.andargunawanpasaribu@yahoo.co.id 
juga mengintegrasikan teknologi pembelajaran, konten digital, dan instruksi. Dengan kata lain, pembelajaran digital menyediakan mekanisme penyampaian alternatif untuk pengajaran berkualitas yang efektif. (Schwartz, 2 014). The pembelajaran online digital, gudang salah satu bentuk dan dirancang untuk mendukung guru adalah dalam fase (i) mengambil objek belajar, melalui mekanisme pencarian berdasarkan kata kunci diterapkan pada repositori yang dipilih; (ii) analisis objek pembelajaran yang dikembalikan, yang informasinya diperkaya dengan konsep metrik relevansi, berdasarkan operasi hasil pencarian dan data yang terkait dengan penggunaan objek pembelajaran sebelumnya dalam mata kuliah yang dikelola dan (iii) importasi objek pembelajaran yang sedang dibangun (Limongelli; 2015).

Perkembangan teknologi informasi membawa transformasi dan perkembangan pendidikan (Perttersson \& Molstad, 2016). Castells juga mengomentari masalah "Teknologi tidak mendefinisikan masyarakat, teknologi adalah masyarakat" (M. Castells, Manuel, The Rise of the Network Society, 1996pp. 158-163, 1996). Perkembangan dinamis TIK yang berkelanjutan dalam pendidikan membawa alat dan pilihan baru. Laju perubahan yang cepat mungkin menjadi alasan banyak orang melihat teknologi sebagai sesuatu yang "diberikan" kepada orang-orang sementara pengertian tentang keberadaan teknologi atau perasaan yang mereka gunakan dalam proses belajar mengajar tidak sepenuhnya jelas. Tapi seperti yang dinyatakan oleh Levy (P. Lévy, 1998 hal. 76,). Lebih lanjut Lev Manovich (2001) membahas tentang lima prinsip yang muncul dari sifat digitalnya, yaitu representasi numerik, modularitas, otomasi, variabilitas dan transcoding (L. Manovich, pp. 36-42,).

Lima kegunaan untuk penghasilan web. Pertama, repositori lebih mudah diakses karena Mahasiswa dapat memasukkan dan mengambil materi pada waktu yang sesuai dan selama yang mereka inginkan. Keuntungan kedua berkaitan dengan kebutuhan masing-masing pelajar, terutama potensi yang ditawarkan materi berbasis web kepada Mahasiswa untuk menjelajahi area tertentu yang mereka anggap sulit untuk dipahami. Ketiga, materi berbasis web menawarkan peningkatan keaslian, dalam hal ini dapat lebih mudah berhubungan dengan apa yang terjadi di 'dunia nyata', sebuah tujuan yang sering dicapai melalui penautan ke situs web organisasi yang bekerja di bidang perawatan sosial tertentu. Keempat, pembelajaran berbasis web menawarkan kesempatan untuk jenis pembelajaran yang lebih aktif, di mana Mahasiswa berinteraksi dengan materi daripada menjadi penerima pasif. kelima, dan sering dikaitkan t o ini, adalah potensi untuk repositori materi berbasis tawaran untuk mengembangkan kekuatan kognitif, dengan mendorong kombinasi dari penelitian melalui pengumpulan informasi dan pemecahan masalah keterampilan. pro cess merancang diakses repositori aplikasi pendidikan berbasis melibatkan dua tindakan utama. Kemudian Mahasiswa dapat memasukkan karya dan kreasi (misal laporan tertulis berupa 
JURNAL CHRISTIAN HUMANIORA

Vol.4, No.2, November 2020, pp. 78-88

p-ISSN: 2598-6317- e-ISSN: 2599-196

laporan penelitian, laporan pengabdian masyarakat, laporan PPL, skripsi, disertasi, makalah, artikel jurnal).

Kebutuhan untuk repositori berbasis untuk membuatnya lebih mudah untuk mengelola data ilmiah mahasiswa dan memfasilitasi Mahasiswa dalam mengumpulkan data yang telah diperoleh dan Mahasiswa secara aktif menarik. Untuk alasan tersebut maka diperlukan sebuah gudang untuk memudahkan dalam pengelolaan karya ilmiah mahasiswa dan memudahkan mahasiswa dalam mengumpulkan karya ilmiah yang telah dikerjakan.

\section{PEMBAHASAN}

Pembelajaran digital juga mengintegrasikan teknologi pembelajaran, konten digital, dan instruksi. Dengan kata lain, pembelajaran digital memberikan mekanisme penyampaian alternatif untuk pembelajaran berkualitas yang efektif. (Schwartz, 2014). The pembelajaran online, gudang salah satu bentuk dan dirancang untuk mendukung guru adalah dalam fase (i) mengambil objek belajar, melalui mekanisme pencarian berdasarkan kata kunci diterapkan pada repositori yang dipilih; (ii) analisis objek pembelajaran yang dikembalikan, yang informasinya diperkaya dengan konsep metrik relevansi, berdasarkan operasi hasil pencarian dan data yang terkait dengan penggunaan objek pembelajaran sebelumnya dalam kursus; dan (iii) importasi objek pembelajaran yang sedang dibangun (Limongelli; 2015) Tujuan dari teknologi pembelajaran adalah untuk mempengaruhi dan mempengaruhi pembelajaran (David M. Schwartz, 2014) Di sisi lain, lingkungan e-learning diimplementasikan, didukung konten pendidikan dan skenario pembelajaran yang sesuai dirancang secara apriori untuk kelompok sasaran (Karampiperi, 2014). Merancang konten pembelajaran berbasis hypermedia yang dapat diakses dan merancang antarmuka yang dapat diakses untuk menjelajahi konten ini. (Johns, 2014).

Untuk membuat aplikasi web dan repositori menarik, mereka perlu divariasikan beberapa fitur utama yang diberikan di bawah ini. Font dan warna. Kombinasi warna harus memperhitungkan persyaratan kontras tinggi. Warna yang paling mudah digunakan untuk digunakan adalah kombinasi terang / gelap atau gelap / terang untuk font dan latar belakang, lebih disukai dalam nuansa yang saling melengkapi (misalnya biru muda dan biru tua lebih baik daripada biru muda dan merah tua). Untuk orang-orang dengan masalah penglihatan, peningkatan ukuran font tidak dapat mengimbangi kombinasi warna yang tidak terbaca. Gambar-gambar. Gambar harus diberi label yang benar dan informasi yang dikandungnya juga harus dapat diakses dengan cara lain; grafik harus mudah diinterpretasikan dan harus dapat diubah ukurannya. Navigasi. Salah satu aturan aksesibilitas standar adalah bahwa tautan harus digarisbawahi jika memungkinkan / praktis (tidak hanya dengan mengarahkan mouse), dan bahwa item yang bukan tautan (mis. Tajuk) tidak 
boleh digarisbawahi. Tidak hanya membuatnya lebih jelas apa itu tautan dan apa yang bukan, tanpa harus mengarahkan kursor ke item untuk menemukannya, ini juga memberi pengguna kemampuan untuk membedakan tautan yang dikunjungi sebelumnya dari tautan yang tidak dikunjungi. Tautan yang diidentifikasi hanya dengan warna tidak menyediakan ini, dan juga dapat menjadi masalah bagi orang dengan masalah penglihatan dan warna. Tata Letak. Salah satu masalah aksesibilitas terpenting yang sering diabaikan adalah pemeliharaan tata letak yang jelas dan sederhana yang konsisten di seluruh situs. Halaman yang berantakan atau rumit, bersama dengan perubahan tata letak di berbagai bagian situs membuat navigasi menjadi sulit dan menyebabkan kebingungan (Diederich, 2014) Tujuan dari teknologi pembelajaran adalah untuk mempengaruhi dan mempengaruhi pembelajaran (David M. Schwartz, 2014) Di sisi lain, lingkungan e-learning diimplementasikan, konten pendidikan yang didukung dan skenario pembelajaran yang sesuai dirancang secara apriori untuk kelompok sasaran (Karampiperi, 2014).

Ada lima kegunaan untuk pembelajaran web. Pertama, pembelajaran berbasis web lebih mudah diakses karena Mahasiswa dapat memasukkan dan mengambil materi pada waktu yang sesuai dan selama yang mereka inginkan. Keuntungan kedua berkaitan dengan kebutuhan masing-masing pelajar, terutama potensi yang ditawarkan materi berbasis web kepada Mahasiswa untuk menjelajahi area tertentu yang mereka anggap sulit untuk dipahami. Ketiga, materi berbasis web menawarkan peningkatan keaslian, dalam hal ini dapat lebih mudah berhubungan dengan apa yang terjadi di 'dunia nyata', sebuah tujuan yang sering dicapai melalui penautan ke situs web organisasi yang bekerja di bidang perawatan sosial tertentu. Keempat, pembelajaran berbasis web menawarkan kesempatan untuk jenis pembelajaran yang lebih aktif, di mana Mahasiswa berinteraksi dengan materi daripada menjadi penerima pasif. Sering dikaitkan dengan ini, adalah potensi materi berbasis web untuk menawarkan pengembangan kekuatan kognitif, dengan mendorong kombinasi penelitian melalui pengumpulan informasi dan keterampilan pemecahan masalah. Proses perancangan aplikasi pendidikan berbasis web yang dapat diakses melibatkan dua tindakan utama: Merancang konten pembelajaran berbasis hypermedia yang dapat diakses dan merancang antarmuka yang dapat diakses untuk menjelajahi konten ini. (Johns, 2014). Dari pada halaman yang berantakan atau rumit, bersama dengan perubahan pada tata letak di berbagai bagian situs membuat navigasi menjadi sulit dan menyebabkan kebingungan (Diederich, 2014).

\section{METODE PENELITIAN}

Populasi dalam penelitian ini adalah seluruh Mahasiswa IAKN Prodi PAK Tarutung. S emester 6 adalah 49 mahasiswa. Penelitian "strategi pembelajaran motivasi dari repositoru terhadap hasil belajar mahasiswa. Menuju Peningkatan Penguasaan Repositori Mahasiswa di Institut Kristen 
JURNAL CHRISTIAN HUMANIORA

Vol.4, No.2, November 2020, pp. 78-88

p-ISSN: 2598-6317- e-ISSN: 2599-196

Negeri Tarutung (IAKN)" menggunakan model pengembangan metode Borg \& Gall Development

Model Research and Development (R\&D) menggunakan aliran air. air terjun (waterfall) pada tahap perkembangannya. (The Borg \& Gall; 2001). Tahapan pengembangan mulai dari Studi Pendahuluan hingga diseminasi diatur secara detail untuk memudahkan pembangunan. Penggunaan penyebaran kuesioner dengan Google Formulir.

Selanjutnya adalah tahap design atau perancangan, jika tahap analisis sistem sudah terpenuhi. Pada tahap perancangan ini juga akan dirancang arsitektur dan perancangan infrastruktur untuk mendukung sistem pengelolaan karya ilmiah berbasis teknologi web yang akan dikembangkan. Pada tahap ini juga akan dilakukan perancangan sistem yang meliputi perancangan basis data, perancangan antarmuka program, dan perancangan proses manipulasi data (input, delete, dan download), serta perancangan proses pencarian. (Munoz, 2015).

Populasi dalam penelitian ini adalah seluruh Mahasiswa IAKN Prodi PAK Tarutung. S emester 6 adalah 49 mahasiswa. Penelitian "strategi pembelajaran motivasi dari repositoru terhadap hasil belajar mahasiswa. Menuju Peningkatan Penguasaan Repositori Mahasiswa di Institut Kristen Negeri Tarutung (IAKN)" menggunakan model pengembangan metode Borg \& Gall Development Model Research and Development (R\&D) menggunakan aliran air. air terjun (waterfall) pada tahap perkembangannya. (The Borg \& Gall; 2001). Tahapan pengembangan mulai dari Studi Pendahuluan hingga diseminasi diatur secara detail untuk memudahkan pembangunan. Penggunaan penyebaran kuesioner dengan Google Formulir.

Selanjutnya adalah tahap design atau perancangan, jika tahap analisis sistem sudah terpenuhi. Pada tahap perancangan ini juga akan dirancang arsitektur dan perancangan infrastruktur untuk mendukung sistem pengelolaan karya ilmiah berbasis teknologi web yang akan dikembangkan. Pada tahap ini juga akan dilakukan perancangan sistem yang meliputi perancangan basis data, perancangan antarmuka program, dan perancangan proses manipulasi data (input, delete, dan download), serta perancangan proses pencarian. (Munoz, 2015).

\section{DISKUSI}

\section{Analisis Kebutuhan}

Berdasarkan analisis kebutuhan dan strategi pembelajaran motivasi dari repositori dengan hasil belajar 49 orang yang mewakili seluruh mahasiswa Program Studi IAKN Tarutung yang menyatakan belum mengetahui tentang Penerapan Pengelolaan Karya Ilmiah dan Bahan Ajar adalah 49, maka 35 dari 49 Mahasiswa 
menyatakan yang mereka ketahui tentang Repository dan 49 Mahasiswa menyatakan bahwa mereka membutuhkan Aplikasi Manajemen. (Lihat Tabel 4: 1) Hasil survei perlu analisis strategi pembelajaran motivasi dari repositoru untuk hasil belajar Mahasiswa.

\begin{tabular}{|c|c|c|c|}
\hline \multirow{2}{*}{ No. } & Type of Information & \multicolumn{2}{|c|}{ Answer } \\
\cline { 3 - 4 } & & Yes & No \\
\hline 1. & Need development of Symbol & 49 & \\
\hline 2. & Need development and Desain Tool of Repository & 35 & 14 \\
\hline 3. & Need development and Desain Tool of Repository & 49 & - \\
\hline 4 & Easy Accessing Repository. & 45 & 4 \\
\hline 5 & Completeness of lecture materials & 49 & - \\
\hline 6 & Assessment of Application Effectiveness & 47 & 2 \\
\hline 7 & Effectiveness Repository & 46 & 3 \\
\hline
\end{tabular}

\section{Kebutuhan Symbol yang jelas di Repository}

Untuk menunjang motivasi belajar perlu dibuat simbol yang menarik. Simbol simbol ini bertujuan untuk memudahkan dan memotivasi mahasiswa dalam mempelajari dan membaca materi perkuliahan. Simbol ini harus sederhana dan mudah diingat. Simbol ini melambangkan mata kuliah baik dalam klasifikasi maupun pemanfaatannya. Diskusui sistem simbol dalam repositori dapat mencakup aspek-aspek berikut: 1) Ikhtisar: Bagian ini memberikan gambaran tingkat tinggi dari dekomposisi struktural dan fungsional dari sistem. Fokusnya adalah bagaimana dan mengapa sistem diuraikan dengan cara ini, bukan pada detail komponennya. Pembahasan juga mencakup informasi tentang peran dan tanggung jawab utama yang harus dijalankan oleh sistem. 2) Rasional Bagian ini mengulas mengapa arsitektur yang dijelaskan dalam bagian a (ikhtisar) digunakan. 3) Component Details Bagian ini memuat ringkasan operasi setiap komponen yang terdapat dalam arsitektur dan bagaimana komponen tersebut berinteraksi satu sama lain. 


\section{Perlu Pengembangan dan Desain Alat Repository.}

Dengan pengembangan dan desain repository yang menarik akan memotivasi belajar mahasiswa.. Alat dalam repositori termasuk investasi dalam perangkat keras, perangkat lunak. Dan alat ini berbasis saintifik dan bahan ajar, sebelum diujicobakan baik pada kelompok pengguna kecil maupun besar, terlebih dahulu divalidasi oleh ahli desain perangkat lunak dan ahli materi. Indikator repositori menurut desain perangkat, tampilan awal aplikasi, tampilan penyajian informasi, tampilan menu, tampilan konten, kesesuaian warna, warna font, ukuran gambar, kejernihan gambar, font yang digunakan, kejelasan huruf, ukuran menu yang disajikan, penamaan menu dan sortir memesan Menu.

\section{Mudah Mengakses Repositori}

Kemudahan mengakses teori juga menentukan motivasi belajar Mahasiswa. Mengakses repositori bisa dilakukan dimanapun dan kapanpun . Pengaksesan bisa dilakukan dengan Facebook, Opera, email atau Gmail dan sebagainya. . Persentase hasil penilaian validator adalah 95\% dimana skor ideal 56 sedangkan berprestasi 53 .

Berdasarkan hasil validasi ahli perancangan perangkat lunak diketahui bahwa Persentase Nilai Kepraktisan (\% NE) mencapai 95\%. artinya aplikasi yang dirancang termasuk dalam kategori Sangat Baik. Lihat Tabel 4.2. Kategori Nilai Praktis

\begin{tabular}{|c|c|}
\hline CATEGORY & Add \\
\hline $75 \% \leq \mathrm{NK}<100 \%$ & Very good \\
\hline $50 \% \leq \mathrm{NK}<74 \%$ & Good \\
\hline $25 \% \leq \mathrm{NK}<49 \%$ & Bad \\
\hline $0 \% \leq \mathrm{NK}<24 \%$ & Very bad \\
\hline
\end{tabular}

\section{Kelengkapan bahan kuliah}

Indikator evaluasi kelengkapan validator ahli materi perkuliahan adalah sebagai berikut: User friendly dari segi penggunaan khususnya bagi mahasiswa dan dosen, tampilan menarik, kesesuaian menu dengan kebutuhan mahasiswa dan dosen, tata letak menu, pemilihan logo dan ikon, kesesuaian konten dengan judul, kualitas 
gambar, Bahasa yang digunakan, tata letak konten, kecepatan memuat, kemudahan menjalankan aplikasi di smartphone, kecepatan dalam menampilkan konten. Dari keseluruhan indikator yang dinilai, tingkat kepraktisan penerapan skor ideal 48 dan skor pencapaian 46, sehingga persentasenya 96\%. .T dia aplikasi yang dirancang dalam kategori Sangat Baik. (Lihat tabel 4.2).

Saran Validator: Kelengkapan materi perkuliahan merupakan input data yang konsisten sehingga semakin memperkaya sumber pencarian dan Usahakan agar tampilan yang menarik, (menampilkan ikon-ikon misalnya gambar pembelajaran mahasiswa on line, dll, seperti terlihat pada gambar di bawah ini.

\section{Penilaian Efektivitas Aplikasi}

Penilaian validator terhadap aplikasi yang telah direvisi kemudian akan diujikan pada pengguna dalam kelompok terbatas (yaitu 10 mahasiswa Prodi PAK). mengumpulkan data tentang efektivitas penggunaan Repository kepada kelompok kecil dengan menyebarkan kuesioner yang diisi secara online.

Berdasarkan hasil pengolahan data tentang keefektifan penggunaan Aplikasi / erepository di IAKN Tarutung seperti pada tabel di atas diketahui bernilai tinggi berada yaitu pernyataan tentang "aplikasi praktis untuk menggunakan "dengan persentase total" 98\%. cara praktis mudah dan senang menggunakannya. Berdasarkan hasil yang diperoleh dari pengolahan data secara keseluruhan, semua item dinyatakan dalam Sangat Efektif Lihat Tabel 4. 3 Kategori Efektivitas Aplikasi.

\begin{tabular}{|c|c|}
\hline Category & Add \\
\hline $75 \% \leq \mathrm{NK}<100 \%$ & Sangat Efektif \\
\hline $50 \% \leq \mathrm{NK}<74 \%$ & Efektif \\
\hline $25 \% \leq \mathrm{NK}<49 \%$ & Not Efektif \\
\hline $0 \% \leq \mathrm{NK}<24 \%$ & Very not Efektif \\
\hline
\end{tabular}

Karena hasil uji coba kelompok kecil menunjukkan hasil yang sangat efektif, maka tim melanjutkan pengujian aplikasi kepada pengguna dalam kelompok besar. 


\section{Tempat Penyimpanan Efektivitas}

Efektivitas penggunaan repositori juga merangsang motivasi belajar Mahasiswa. Efektivitas ini karena adanya pelayanan, kategorisasi, pengelompokan dan fungsi. T dia efektivitas Data dari menggunakan repositori ini, kuesioner online dibagikan. Kuesioner yang dikumpulkan secara online kemudian ditabulasi dan diolah sehingga hasilnya dapat dilihat pada tabel berikut;

Berdasarkan hasil pengolahan data tentang keefektifan e-Repository di IAKN Tarutung seperti pada tabel diatas diketahui bahwa pernyataan responden yang bernilai tinggi berada pada P8 yaitu pernyataan tentang "Aplikasi Praktis yang Digunakan" dengan persentase total "96\%. praktis artinya mudah dan senang menggunakannya. Berdasarkan hasil yang diperoleh dari pengolahan data secara keseluruhan, semua item dinyatakan dalam kategori Sangat Efektif (lihat tabel 4.3).

\section{SIMPULAN}

Kesimpulan dari penelitian ini adalah bahwa strategi motivasi belajar dari gudang meningkatkan hasil belajar Mahasiswa. S trateg adalah motivasi belajar sangat bermanfaat bagi Mahasiswa, mereka dapat diambil kembali untuk digunakan sebagai acuan dalam penyelesaian tugas akhir. Begitu juga dengan skripsi, jurnal, laporan, laporan pengabdian masyarakat, skripsi bahkan disertasi bisa menjadi masukan ke dalam aplikasi. Dengan adanya aplikasi ini permasalahan mengenai tugas Mahasiswa, jurnal dan sejenisnya dapat teratasi. Dosen dan siapapun dapat mengambil dan memberikan informasi melalui aplikasi. Maka dari itu, jika dikaitkan dengan situasi pandemi saat ini, aplikasi seperti ini sangat berguna bagi siapa saja yang membutuhkan informasi seputar ilmu pengetahuan. Repositori menyeluruh. Bahkan dalam situasi "social distancing", bahan ajar berbasis repositori dapat mengatasi ruang dan waktu. Meski masih di rumah, pembelajaran tetap berjalan, karena pembelajaran menggunakan ini sangat praktis, seperti yang dikemukakan oleh pengguna sebagai responden dalam uji coba instrumen ini.

\section{KEPUSTAKAAN}

A, J. D. (2014). REASE-The repository for learning. New Review of Hypermedia and, 2011-237. 
Archer, A. \&. (2016). Transitional and Transformational Spaces: Monitoring Young Academics, Through Writing Center,. Education as Change,20(10, 43-58.

B PK. (2014). Supporting accessible hypermedia. New Review of Hypermedia and, 37-41.

Borg, W. R. (2003). Educational Research: An Introduction. New York: Logman.

Briskey, C. V. (2014). ICT driven pedagogies and its impact on learning. International Journal of Pedagogies and Learning, 73-83.

Gall, M. D. (2007). Application of Education Research. Boston: Pearson Education: Inc.

Lane, A. (2017). The impact of technology on the teaching and assessment of. Open Learning: The Journal of Open, Distance and eLearning, 1-17.

Limongelli, C. M. (2015 ). A recommendation module to help. New Review of Hypermedia and Multimedia, Francis Taylor, 1-25.

M, C. M. (1996). The Rise of The Network Society, The Information Age: Economy, Society, and Culture. Cambridge, MA: Oxford, UK: Blackwell, Vola, 158-163.

Manovich, L. (2001). Language of New Media. Cambridge: MT.Press, 36-42.

Muñoz, O. R., \& Sánchez, F. A. (2015). The Skills, Competences, and Attitude toward. New Review of Hypermedia and Multimedia, Francis Taylor, 83-110.

Nicholas, P. (2011). A Snowball in Africa with a Chance of Flourishing: Writing centers as Shifters of Power in A South African. Current Writing: Text ad Reception in South Africa 10(2).

P.Levy. ( 1998). Becoming virtual. New York: Plenum Trade, 76.

Pertterson, D. \&. (2016). PISA Teacher: Hope and Happening of Educational development, Educate, and Sociedade. Ijelss 37( 136), 629-645.

Pragg, K. (2014). Tertiary Education and Direction for Future Research: Accommodating the shifting demographics of Caribbean"s tertiary Student. Journal of the Department of Behavioural Sciences 3(1), 65-80.

Rafoth, B. (2010). Why visit your campus writing center. Writing Spaces: Readings on Writing, 140-155.

Robert, J. (2014). Application of Web-based learning in. Social Work Education: The, 429-443.

S, C. (2011). Writing in The Academic: Collaboration Writing development with Students and Lectures at the UWC Center. Rhodes University, Cohen et al.200 Reseaxrc Method In Education, Great Britain: TJ International Ltd, Padstow Cornwall.

Sabah, A. F. (2014). Developing Web Application, International, . International Journal of Software Engineering and Its Application 5(2).

Sadler, P. M. (2009). Engineering Competitions in the Middle School. Journal of the Learning Sciences, 299-327. 


\section{JURNAL CHRISTIAN HUMANIORA}

Vol.4, No.2, November 2020, pp. 78-88

p-ISSN: 2598-6317- e-ISSN: 2599-196

Schwartz, D. M. (2014). Breaking Through Barriers: Using Technology. Applied Neuropsychology: Child, 173-181.

Sharma, G. \&. (2010). Importance of Soft Skill Development in the 21st Century Curriculum. International Journal Of Education and Allied Sciences, vol 2 no 2 , $39-44$.

Yeats, R., P, R., \& Wheeler, A. \&. (2010). What a Difference a Writing Center makes: A Small Scale Study, Education, and Training, 52. Retrieved From DOI 10.1108/004, 4999507 